\title{
Grazing and Grazing Exclusion Along a Resource Gradient in Magellanic Meadows of Tierra del Fuego
}

\author{
Marta B. Collantes, ${ }^{1}$ Celina Escartín, ${ }^{2}$ Karen Braun, ${ }^{3}$ Ana Cingolani, ${ }^{4}$ and Juan Anchorena ${ }^{5}$ \\ Authors are ${ }^{1}$ Research Scientist, ${ }^{2}$ PhD Student, ${ }^{3}$ Postdoctoral Researcher, ${ }^{5}$ Rangeland Scientist, Consejo Nacional de Investigaciones Científicas y \\ Técnicas, Dept of Botany, Museo Argentino de Ciencias Naturales, Ángel Gallardo 470, 1405DJR, Ciudad Autónoma de Buenos Aires, Argentina; and \\ ${ }^{4}$ Research Scientist, Instituto Multidisciplinario de Biología Vegetal, Consejo Nacional de Investigaciones Científicas y Técnicas, Facultad de Ciencias \\ Exactas Físicas y Naturales, Universidad Nacional de Córdoba, Vélez Sársfield 299, CC495, 5000, Córdoba, Argentina.
}

\begin{abstract}
Although Magellanic meadows have been subject to ungulate herbivory for a long time; they have suffered severe grazing by domestic sheep since the end of the 19th century. We hypothesized that, if protected from grazing, the present dominant dwarf forms would be replaced by taller competitive forms, mainly grasses. We then monitored floristic composition along a gradient of soils over periods of 5 to 16 yr on seven meadow sites under grazing and, in five, also on exclosures. Initial and final floristic samples were classified with TWINSPAN and ordinated with Detrended Correspondence Analysis (DCA). We also tracked cover changes in life-forms (grasses, dwarf sedges/rushes, rhizomatous helophytes, and cushion shrubs). At the end of the study, we assessed floristic similarity between paired grazed and exclosed treatments, and compared their life-form cover, diversity, biomass, and soil compaction with Student's $t$ and Mann-Whitney's tests. Temporal displacements of composition in ordination space showed the effect of a long drought (DCA axis 1) and of grazing removal (DCA axis 2). Grazing exclusion had a much greater impact in wet meadows-where grasses became the dominant life-form-than in dry meadows. The effect of drought was shown in 1) the expansion of the cushion shrub Azorella trifurcata (Gaertn.) Pers. in both grazed and nongrazed treatments of the drier wetlands; 2) the decrease in Caltha sagittata Cav. in riparian meadows, and its encroachment under grazing in the wettest spring meadow; and 3) the large increase in Poa pratensis L. in exclosed wet meadows. Despite this strong response to environmental conditions, overall results supported the idea that these wetlands are equilibrium systems. Although the drier meadows have crossed an irreversible threshold, the Caltha-encroached wet meadows returned to a grass state in about 4 yr when protected from grazing. Their resilience suggests that they could be partly restored with rest-rotation grazing.
\end{abstract}

Key Words: equilibrium, plant-animal interactions, plant community dynamics, riparian ecology, state-and-transition

\section{INTRODUCTION}

Introduction of domestic herbivores in semiarid regions of the new world has severely degraded wetlands, a key component of grazing lands (Armour et al. 1994; Belsky et al. 1999). A frequent effect of grazing on wetlands is the replacement of different life-forms that are indicative of ecosystem function or health. Generally, grazing favors small-statured species, especially dicotyledonous rosettes, and decreases biomass of dominant taller species, mainly grasses (Humphrey and Patterson 2000; Stammel et al. 2003; Collantes et al. 2005).

However, reports on life-form response have been somewhat contradictory. For instance, the persistence or increase with grazing of sedges and rushes, even when they were palatable, was attributed to their strong rhizome system (Allen and Marlow 1994; Collantes et al. 2005) or to other grazing resistance traits (Schulz and Leininger 1990). Other papers have reported a decrease in this life-form with grazing (Green and Kauffman 1995; Martin and Chambers 2001). Shrubs

Research was funded by the Agencia Nacional de Promoción Científica y Tecnológica under Grant Nos. PICT 403/3458 and 14198.

Correspondence: Marta B. Collantes, Dept of Botany, Museo Argentino de Ciencias Naturales, Angel Gallardo 470, Ciudad Autónoma de Buenos Aires, 1405DJR, Argentina. Email: collantes@macn.gov.ar

Manuscript received 2 November 2011; manuscript accepted 2 July 2013.

(c) 2013 The Society for Range Management strongly affect ecosystem function and increase in overgrazed wetlands in semiarid regions (Weixelman et al. 1997; Chambers and Linnerooth 2001), whereas in more mesic climates, they invade abandoned humid pastures (Middleton 2002; Matějková et al. 2003; Bork and Burkinshaw 2009). While several studies have shown that grazing increased wetland diversity (Smith and Rushton 1994; Green and Kauffman 1995; Jensen and Schrautzer 1999; Humphrey and Patterson 2000), others have reported negative or neutral effects (Bakker and Grootjans 1991; Matějková et al. 2003; Lucas et al. 2004). Middleton et al. (2006) suggested that many of these apparent inconsistencies were probably due to differences in regional environments, wetland types, and/or stocking rates among studies.

It is generally accepted that heavy grazing reduces wetland productivity (Weixelman et al. 1997; Beck and Peek 2004) and that when grazing pressure is lowered or suppressed, a change to a more productive state takes place (Buttolph and Coppock 2004). Nevertheless, results are not consistent (Clary 1995; Martin and Chambers 2001), suggesting that some degree of grazing might stimulate production by overcompensation, a mechanism more expected to occur in mesic ecosystems (Belsky 1987). Livestock trampling contributes to this varied response, having direct and indirect site-dependent effects on vegetation structure and on wetland hydrology (Bryant et al. 1972; Clary 1995; Weixelman et al. 1997; Wheeler et al. 2002). Possibly due to this complexity, conceptual models of the ecological 
effects of ungulate grazing on wetlands are scarce (but see Allen-Diaz and Jackson 2000; Stringham et al. 2001; Wright and Chambers 2002; Buttolph and Coppock 2004, and Collantes et al. 2005 for studies using alternative state concepts in wetlands).

Northern Tierra del Fuego is part of the Magellanic region, a more humid and oceanic variant of the Patagonian steppe. Sheep grazing was the activity around which the island's economy developed in the $20^{\text {th }}$ century. Twenty ranches cover around $5000 \mathrm{~km}^{2}$ with about 290000 sheep and 9000 cattle. Most sheep are of the Corriedale breed, raised for wool and meat. Despite the harsh climate, most land supports year-round grazing. Early fencing of large areas (2 000-4 000 ha) favored heterogeneous animal distribution and overgrazing. Wetlands cover $15-20 \%$ of the land surface and represent a key forage resource. Since the end of the Pleistocene, these rangelands evolved under grazing by native camelids (guanacos) (Raedecke 1980). Based on historical estimates of population size (Lauenroth 1998), these grazers probably imposed a relatively high seasonal pressure on meadows, the main type of freshwater wetlands in the steppe area. When European settlers arrived at the end of the $19^{\text {th }}$ century, the main life-forms in these meadows were grasses, sedges, and rushes (Dusén 1905). Sheep overgrazing led to encroachment of unpalatable plants, especially the rhizomatous helophyte Caltha sagittata Cav. and the cushion shrub Azorella trifurcata (Gaertn.) Pers. The associated severe reduction of palatable grasses (Collantes et al. 2005, 2009) is perceived by ranchers as the main cause of decline in sheep reproduction (Anchorena et al. 2001). We assumed that these wetlands, being dominated by perennial herbaceous vegetation and with relatively continuous inputs of water and nutrients, are predictably affected by grazing intensity (i.e., they behave as equilibrium systems).

It was hypothesized that, after more than a hundred years of domestic grazing, these meadows reached relatively stable states dominated by dwarf, grazing-resistant life-forms, and that grazing exclusion would favor taller competitive species, especially grasses. The recovery of grass species will decrease plant diversity and increase productivity. Taking advantage of long-term exclosures, we assessed the effects of grazing and grazing exclusion on species composition and life-form dynamics across a water-table gradient in Magellanic meadows, interpreting results using alternative states-and-transition concepts. We used permanent plots in order to follow pathways of succession (Bakker et al. 1996) and used multivariate analysis to separate spatial effects from those of management (Friedel 1991). In that context, the crossing of structural as well as functional thresholds was assessed considering the time needed for key life-forms to replace one another as cover components in each meadow type.

\section{METHODS}

\section{Study Area}

Meadows of the Magellanic region cross two main environmental gradients: a latitudinal climatic gradient of increasing rainfall and decreasing temperature towards the southwest, and a topographic gradient that locally controls the water table depth (Collantes et al. 2009). The resulting floristic gradient was divided by Collantes et al. into two vegetation types: dry and wet meadows.

Dry meadows are common on elevated or border sectors of valleys and have mineral soils and a water table from 50 to more than $100 \mathrm{~cm}$ deep in summer. Dry-meadow vegetation is rich in grasses (Poa pratensis L., Hordeum pubiflorum Hook.f., Festuca magellanica Lam.), forbs (Acaena magellanica [Lam.] Vahl, Taraxacum officinale Weber), and sedges (mainly Carex macrosolen Steud.). The flat helophyte Caltha sagittata (hereafter referred as Caltha) is common, as is the cushion shrub Azorella trifurcata (hereafter referred as Azorella), a species common in dry upland habitats.

Wet meadows have organic soils or mineral soils with organic epipedon, and a water table between $0-40 \mathrm{~cm}$ in summer. They occupy depressed areas of valleys and are characterized by dwarf sedges (Carex vallis-pulchrae Phil., C. macrosolen), rushes (Juncus scheuchzerioides Gaudich.), and soft grasses (Hordeum lechleri [Steud.] Schenck, Deschampsia antarctica Desv., and P. pratensis, among others). Frequently, they are dominated by Caltha. Wet meadows can be subdivided into two types: riparian wet and spring-fed. Riparian wet meadows (which are acidic) are recharge wetlands occurring on stream banks with mineral soils (groundwater at 20-40 cm), whereas spring-fed meadows (which are eutrophic) are fed by discharges (seeps) having $\mathrm{Ca}^{2+}$-rich organic soils (groundwater at $0-20 \mathrm{~cm})$.

\section{Study Sites and Design}

The study was conducted in seven meadow sites of the Magellanic steppe, selected from among the sites sampled by Collantes et al. (2009) to represent the full wetland gradient. This gradient can be expressed by the soil type, which is indicative of water table depth. Of the seven selected sites, three were dry meadows (one on Fluvisol, two on Mollic Gleysols) and four were wet meadows (two on Histic Gleysols, and two on Histosols) at different latitudinal locations, from lat $53^{\circ} 26^{\prime} 22^{\prime \prime} \mathrm{S}$ to lat $53^{\circ} 47^{\prime} 43^{\prime \prime} \mathrm{S}$ (330 to $400 \mathrm{~mm}$ rainfall) (Table 1). Exclosures of around $800 \mathrm{~m}^{2}$ were built in sites 1 (Fluvisol), 2 (Mollic Gleysol), and 4 (Histosol) in 1990, and in sites 3 (Mollic Gleysol) and 5 (Histic Gleysol) in 1996. Grazed areas of the same size as the exclosures were selected in the same area, but at a distance sufficient to ensure such that grazing behavior was not affected by nearness of the grazed areas to exclosures. Floristic similarities between exclosures and grazed areas (Sørensen index, Mueller-Dombois and Ellenberg 1974) ranged from $68 \%$ to $80 \%$ when the sampling started, one year after the exclosures were built. This is about the maximum similarity that can be expected for replicate stands (MuellerDombois and Ellenberg 1974). Cover of the four life-forms (grasses, sedges and rushes, helophytes, and cushion shrubs; see the Data Analysis section) selected for the analysis of vegetation dynamics was also similar between adjacent treatment areas, except for grasses on site 5, which had a higher cover in the exclosure.

The studied sites were located in large paddocks ( 2000 $2500 \mathrm{ha}$ ) managed under long-term continuous grazing with an average stocking of around 1 sheep $\cdot \mathrm{ha}^{-1} \cdot \mathrm{yr}^{-1}$. However, grazing pressure on meadows (about $15 \%$ of paddocks, with the remaining $85 \%$ being upland communities) is highly 
Table 1. Characteristics of the seven study sites and dates of exclosure fence building and sampling surveys. Soil groups and soil parameters are from Collantes et al. (2009).

\begin{tabular}{|c|c|c|c|c|c|c|c|c|c|}
\hline Sites & Latitude/ longitude & Vegetation type & FA0 ${ }^{1}$ Soil Group & $\mathrm{pH}$ & C (\%) & $\mathrm{C} / \mathrm{N}$ & Base sat. (\%) & Year of exclusion initiation & Years of floristic surveys ${ }^{2}$ \\
\hline \multirow[t]{2}{*}{1} & $53^{\circ} 26^{\prime} 22^{\prime \prime} \mathrm{S}$ & Dry meadow & Fluvisol & 6.6 & 5.4 & 9.2 & 95 & 1990 & 1991 \\
\hline & $68^{\circ} 14^{\prime} 07^{\prime \prime} W$ & & & & & & & & 2004 \\
\hline \multirow[t]{2}{*}{2} & $53^{\circ} 41^{\prime} 19^{\prime \prime} \mathrm{S}$ & Dry meadow & Mollic Gleysol & 7 & 11.8 & 10.4 & 95 & 1990 & 1991-1994 \\
\hline & $68^{\circ} 09^{\prime} 34^{\prime \prime} W$ & & & & & & & & 2004 \\
\hline \multirow[t]{2}{*}{3} & $53^{\circ} 45^{\prime} 32^{\prime \prime} \mathrm{S}$ & Dry meadow & Mollic Gleysol & 6.2 & 9.4 & - & - & 1996 & 1997-1999 \\
\hline & $68^{\circ} 09^{\prime} 29^{\prime \prime} W$ & & & & & & & & 2004 \\
\hline \multirow[t]{3}{*}{4} & $53^{\circ} 41^{\prime} 19^{\prime \prime} \mathrm{S}$ & Spring-fed meadow & Sapric Histosol & 7 & 33.1 & 12 & 98 & 1990 & $1991-1995$ \\
\hline & $68^{\circ} 09^{\prime} 34^{\prime \prime} W$ & & & & & & & & 2004 \\
\hline & & & & & & & & & 2007 \\
\hline \multirow[t]{3}{*}{5} & $53^{\circ} 45^{\prime} 32^{\prime \prime} \mathrm{S}$ & Riparian wet meadow & Histic Gleysol & 5.7 & 19.1 & 9.5 & 87.7 & 1996 & 1997-2001 \\
\hline & $68^{\circ} 09^{\prime} 28^{\prime \prime} W$ & & & & & & & & 2004 \\
\hline & & & & & & & & & 2007 \\
\hline \multirow[t]{2}{*}{6} & $53^{\circ} 47^{\prime} 43^{\prime \prime} \mathrm{S}$ & Spring-fed meadow & Sapric Histosol & 6.3 & 47.8 & 19.7 & 93 & - & 1996 \\
\hline & $68^{\circ} 10^{\prime} 02^{\prime \prime} \mathrm{W}$ & & & & & & & & 2002 \\
\hline \multirow[t]{2}{*}{7} & $53^{\circ} 45^{\prime} 11^{\prime \prime} \mathrm{S}$ & Riparian wet meadow & Histic Gleysol & 5.6 & 11.7 & 10.8 & 81.9 & - & 1997 \\
\hline & $68^{\circ} 10^{\prime} 33^{\prime \prime} \mathrm{W}$ & & & & & & & & 2002 \\
\hline
\end{tabular}

${ }^{1}$ FAO indicates Food and Agriculture Organization of the United Nations.

${ }^{2}$ In grazing areas and exclosures. The date ranges indicate periods with yearly measurements.

variable. In one of the paddocks, a mean stocking rate in the meadow area of 3.2 sheep $\cdot \mathrm{ha}^{-1} \cdot \mathrm{yr}^{-1}$ was estimated, with peaks in summer of 10 sheep $\cdot \mathrm{ha}^{-1}$ (Anchorena et al. 2001).

Weather data were obtained from the headquarters of a ranch located at lat $53^{\circ} 47^{\prime} \mathrm{S}$ and long $67^{\circ} 42^{\prime} \mathrm{W}$. The 30 -yr average total annual precipitation is $361 \mathrm{~mm}$, falling as rain and snow, and having a slight seasonal peak in DecemberJanuary (Anchorena et al. 2001). During the periods of the study, mean annual rainfall was lower than the long-term average (332.5 mm in 1989-2004 and $291 \mathrm{~mm}$ in 1996-2004), with several years below $220 \mathrm{~mm}$ during a drought cycle between 1995 and 2004.

\section{Field Studies}

Hydrology. To characterize the hydrology of each meadow type, the depth of the water table was monitored in two dry meadows (sites 2 and 3) and in two wet meadows (sites 4 and 5) at different seasons from 2004 to 2007. Measurements (one per season) were taken with slotted plastic pipes placed in boreholes $150 \mathrm{~cm}$ deep. In the summer of 2004-2005, the same procedure was also used in the dry meadow of site 1 .

Floristic Composition. In summer (February), the percentage foliar cover of each species was visually estimated by the same observer on 10 permanent quadrats of $0.2 \times 0.5 \mathrm{~m}$ placed at 2$\mathrm{m}$ intervals along a $20-\mathrm{m}$ line installed in each treatment of each site. The length of the study varied between 5 and $16 \mathrm{yr}$ depending upon the site, with yearly measurements taken for the first 4-6 yr and at variable intervals for the rest of the study (Table 1). The final date of sampling was 2004 for most sites. In February 2007, an additional sampling was carried out in wet meadow sites 4 and 5 after the observation of changes in the exclosures following two yr of above-average rainfall.

Biomass. In February 2004, above-ground biomass was harvested in the exclosures and in the adjacent grazed plots.
Herbaceous material was cut at $1-1.5 \mathrm{~cm}$ above ground level in ten quadrats of $0.2 \times 0.5 \mathrm{~m}$ placed at random in the exclosure. In the grazed area, the same number of quadrats was cut inside 3 to $51.5 \times 1.5 \mathrm{~m}$ cages installed in February of the previous year. Harvested biomass samples were processed in the laboratory and separated into three classes (green graminoids, green forbs, and standing dead biomass), oven-dried at $60^{\circ} \mathrm{C}$ until a constant weight was reached, and then weighed.

Soil Compaction. We estimated soil compaction $(\mathrm{n}=50)$ with a Proctor penetrometer with a needle of $0.65 \mathrm{~cm}^{2}$ at the final date of sampling (2004) on the five paired grazed-ungrazed plots. The operator penetrated the soil for a distance of at least $5 \mathrm{~cm}$ and read the graduated driving shaft. The reading $(\mathrm{kg})$ was divided by the needle size $\left(\mathrm{cm}^{2}\right)$ and converted to resistance units $\left(\mathrm{kN} / \mathrm{m}^{2}=\mathrm{kPa}\right)$ by multiplying by 98.07 (Bradford 1986).

\section{Data Analysis}

To explore the relationship between the moisture gradient and the vegetation response to grazing, we performed multivariate analyses with the floristic censuses from the initial and final sampling dates for the seven sites. First, we carried out an indirect ordination (Detrended Correspondence Analysis, DCA) with a vegetation data matrix of 24 samplings ([5 sites $\times 2$ grazing treatments +2 sites $\times 1$ grazing treatment $] \times 2$ sampling dates) and 49 species, with downweighting of rare species (PC-ORD 5, McCune and Grace 2002). Pearson's Correlation Analysis was conducted to determine the relationship of life-forms with the DCA axes. Second, we classified the 24 plots with a polythetic classification method (TWINSPAN, PC-ORD 5, McCune and Grace 2002) considering species cover in six ranks or cut levels: $0,1,2.5,5,10,20$, and $40 \%$. To interpret temporal changes, groups formed at the second level of division were assimilated to "domains" (sensu Friedel 1991) and characterized by key species and life-forms. 


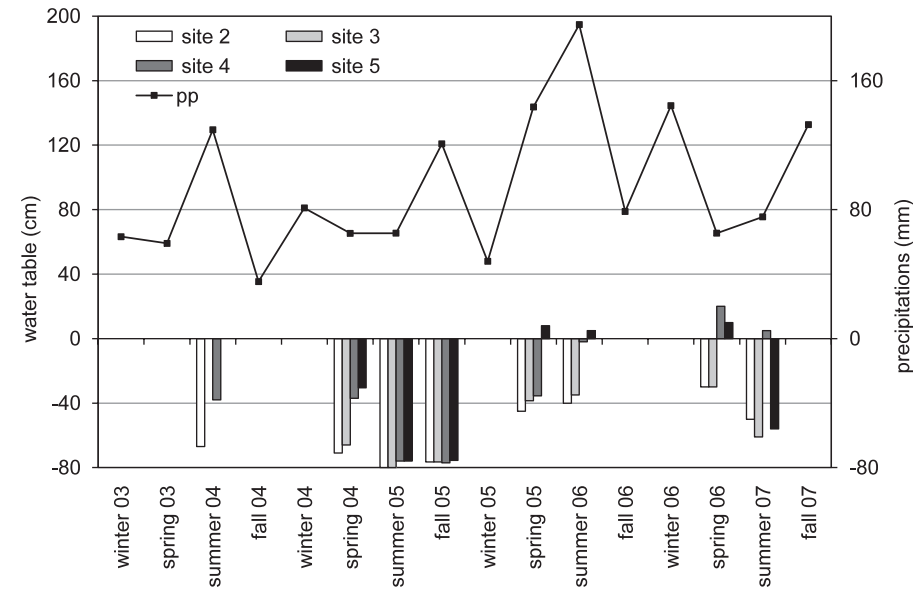

Figure 1. Seasonal precipitation (line) from winter 2003 to fall 2007 and water table depth (bars) from summer 2004 to summer 2007, for dry meadows (sites 2 and 3) and both kinds of wet meadows (spring-fed and riparian, sites 4 and 5, respectively).

We performed several comparisons between paired grazing and exclosure treatments, which were done separately for each site. First, in sites having several years of floristic measurements (sites 2, 4, 5, see Table 1), we compared temporal trajectories of life-forms cover under both treatments. The permanent quadrats allowed us to follow the trajectories of the same plants or clones during the study length. We considered the following four life-forms (Collantes et al. 2009): rhizomatous helophytes (Caltha), cushion shrubs (Azorella), dwarf sedges/ rushes (C. macrosolen, C. vallis-pulchrae, J. scheuchzerioides), and grasses (any grass except the tussock Festuca gracillima Hook. f.). Cover values for each life-form were calculated as

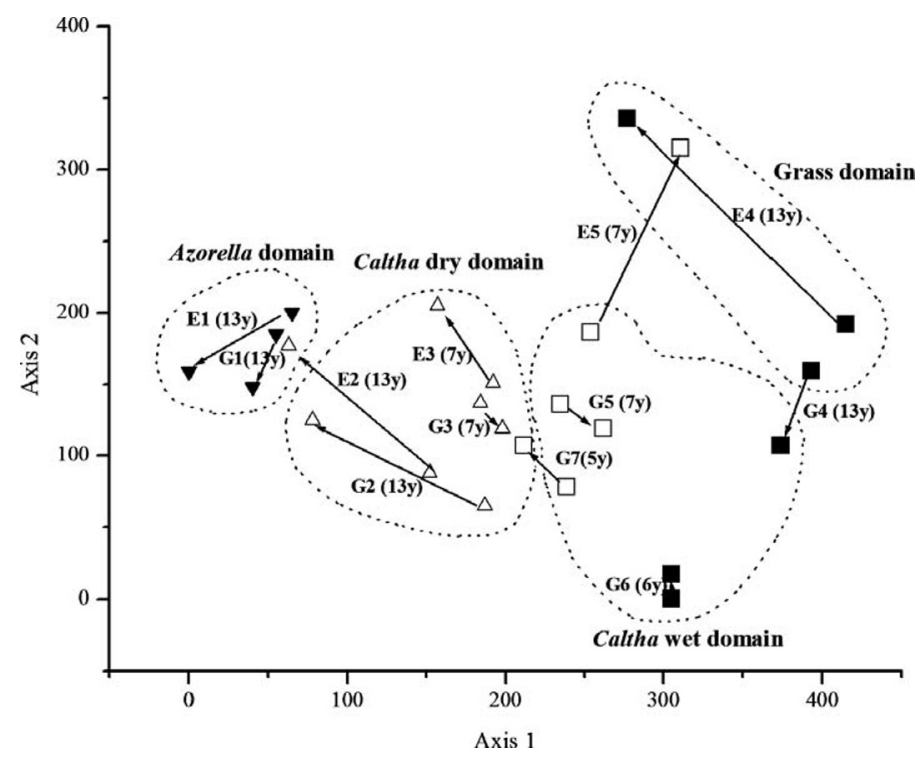

Figure 2. DCA ordination diagram of floristic samples at initial and final dates for different Magellanic meadow types. $\boldsymbol{\nabla}$ Dry meadows on Fluvisols. $\Delta$ Dry meadows on Mollic Gleysols. $\square$ Spring-fed wet meadow. $\square$ Riparian wet meadow. Arrows show size and direction of compositional change, with treatment (G-grazed; E-exclosed), site number and years between initial and final measurements. TWINSPAN groups are encircled and referred to as compositional domains. the sum of species cover of that form, and changes between treatments for each meadow in each year were assessed. Normality of the distribution was verified using the ShapiroWilk test, and we used the Student's $t$ test in the case where the two population variances were equal (Levene's test). If they were not equal, the separate $t$ test for means was used (InfoStat 2008).

To evaluate the effect of cessation of grazing on wetland structure, we compared mean differences in life-form cover; diversity (Simpson index, $\mathrm{D}=1-\sum\left(p_{i} \cdot p_{i}\right)$, where $p_{i}$ is the proportion of individuals belonging to species $i$, PC-ORD 5); herbaceous peak biomass; and soil compaction between paired, adjacent grazed and protected plots for each meadow in 2004. Normality was tested as described above and confirmed for all variables except soil compaction. Differences in this case were tested with the Mann-Whitney test (InfoStat 2008). We compared floristic similarity (Sørensen index quantitative modification, Mueller-Dombois and Ellenberg 1974) between grazed and exclosed plots. To test the differences between water table depths among wetland sites, we compared the annual averages of seasonal measures of water depth with oneway analysis of variance.

\section{RESULTS}

\section{Rainfall and Hydrological Regimes}

Mean water table depths were $105 \mathrm{~cm}$ for the dry meadow on Fluvisol (site 1); $50-53 \mathrm{~cm}$ for dry meadows on Mollic Gleysols (sites 2 and 3); $24.3 \mathrm{~cm}$ for the riparian wet meadow on Histic Gleysol (site 5); and $18.9 \mathrm{~cm}$ for the spring meadow on Histosol (site 4). According to the Tukey test $(P<0.05)$, these differences were significant, except for site 5 , which did not differ from sites 3 and 4 . The seasonal variation of the water table between 2004 and 2007 for sites 2-5, together with seasonal precipitation from the winter of 2003 up to the end of the study, is shown in Figure 1. The long drought (1994-2004) and the relatively low precipitation in the spring-summer periods of 2003-2004 and 2004-2005 caused the low water in 2004, which lasted until autumn 2005. This behavior was reversed after spring 2005, with higher water storage during fall-winter $(43.4 \mathrm{~mm}$ more than the previous year) and unusually high precipitation in late spring-early summer 2006. These high water levels lasted until the summer of 2007, when they dropped again following a dry spring. We observed a noticeable lag in the response of the spring-fed meadow (site 4) compared with the riparian wet meadow (site 5), for both water level declines and increases.

\section{Compositional Gradients and Transitions}

Soil moisture and grazing greatly affected species composition and community structure. The ordination diagram (Fig. 2) shows axes 1 and 2 of the DCA. Axis 1, with an eigenvalue of 0.63 , accounted for $21.7 \%$ of total variance and was positively associated with the dwarf rush/sedges life-form, which is very abundant in spring-fed meadows, and negatively associated with cushion shrubs (mainly Azorella) (Table 2). This axis mainly reflects the spatial wetness gradient, with the dry meadow at the lowest latitude (Fluvisol, site 1) scoring the 
Table 2. Pearson's correlation coefficients of life-forms with Detrended Correspondence Analysis (DCA) axes.

\begin{tabular}{llc}
\hline & Axis 1 & Axis 2 \\
\hline Grasses & 0.029 & $0.839^{\star * *}$ \\
Sedges and rushes & $0.712^{\star \star *}$ & $-0.548^{\star *}$ \\
Rhizomatous helophytes & 0.243 & $-0.445^{\star}$ \\
Woody cushions & $-0.807^{\star \star *}$ & -0.093 \\
\hline
\end{tabular}

${ }^{*} P<0.05$.

$* * P<0.01$

$* \star * P<0.001$

lowest, followed by the dry meadow at intermediate latitude (Mollic Gleysol, site 2), then dry meadow of higher latitude (Mollic Gleysol, site 3), riparian wet meadows (Histic Gleysols, sites 5 and 7), and the spring-fed wet meadows (Histosols, sites 4 and 6) scoring the highest. Axis 2, with an eigenvalue of 0.36 , accounted for $12.5 \%$ of total variance; it was positively associated with grasses and negatively with dwarf sedges and Caltha (Table 2), reflecting mainly grazing-no grazing differences.

Four groups were formed following the divisions at the second level of the TWINSPAN. Important forage species and different life-forms, indicators of site potential as well as disturbance, characterize these groups (Table 3). The groups can be interpreted as forming "domains" or "basins of attraction" (sensu Friedel 1991). Three groups: I, “Azorella domain"; II, "Caltha dry domain"; and III, "Caltha wet domain," separate along axis 1 (Fig. 2), suggesting the control of soil type and water table depth on vegetation types. One group separates along axis 2 (group IV “Grass domain”), indicating the exclosure effects on wet meadows. Under grazing, relatively large, undesirable transitions (large increases of dwarf forms and decreases of grasses) occurred in the most humid site (G4) and in the two driest sites (G1, G2). Sites with intermediate moisture, already encroached with Caltha at the start of the study (G3, G5, G6, G7), underwent short transitions, i.e., minimal change in composition. On the other hand, grazing exclusion produced large desirable transitions (increase in grasses and decrease in dwarf forms) in the three

Table 3. Number of plots of the two meadow types and mean percent cover of forage grasses and other species or life-forms of grazing importance in the four ecological domains determined by the TWINSPAN analysis. Main contributions to total cover are in bold type.

\begin{tabular}{lcccc}
\hline & $\begin{array}{c}\text { Azorella } \\
\text { domain }\end{array}$ & $\begin{array}{c}\text { Caltha dry } \\
\text { domain }\end{array}$ & $\begin{array}{c}\text { Caltha wet } \\
\text { domain }\end{array}$ & $\begin{array}{c}\text { Grass } \\
\text { domain }\end{array}$ \\
\hline Dry meadows & 5 plots & 7 plots & - & - \\
Wet meadows & - & 1 plot & 7 plots & 4 plots \\
Poa pratensis & $\mathbf{7 . 0 5}$ & 2.45 & 1.44 & $\mathbf{1 7 . 4 2}$ \\
Festuca magellanica & 5.16 & 5.60 & 2.17 & 0.57 \\
Hordeum pubiflorum & 2.21 & 6.87 & 0.90 & 0.00 \\
Hordeum halophilum & 0.00 & 0.23 & 2.93 & $\mathbf{7 . 6 1}$ \\
Hordeum lechleri & 0.00 & 0.31 & 1.91 & $\mathbf{2 5 . 8 6}$ \\
Sedges \& rushes & 0.11 & $\mathbf{9 . 2 3}$ & $\mathbf{2 3 . 5 5}$ & $\mathbf{2 7 . 1 6}$ \\
Helophytes (Caltha sagittata) & 1.34 & $\mathbf{2 5 . 7 7}$ & $\mathbf{3 8 . 2 6}$ & 2.59 \\
Cushion shrubs (Azorella trifurcata) & $\mathbf{2 8 . 8 2}$ & $\mathbf{7 . 9 9}$ & 0.29 & 0.29 \\
\hline
\end{tabular}

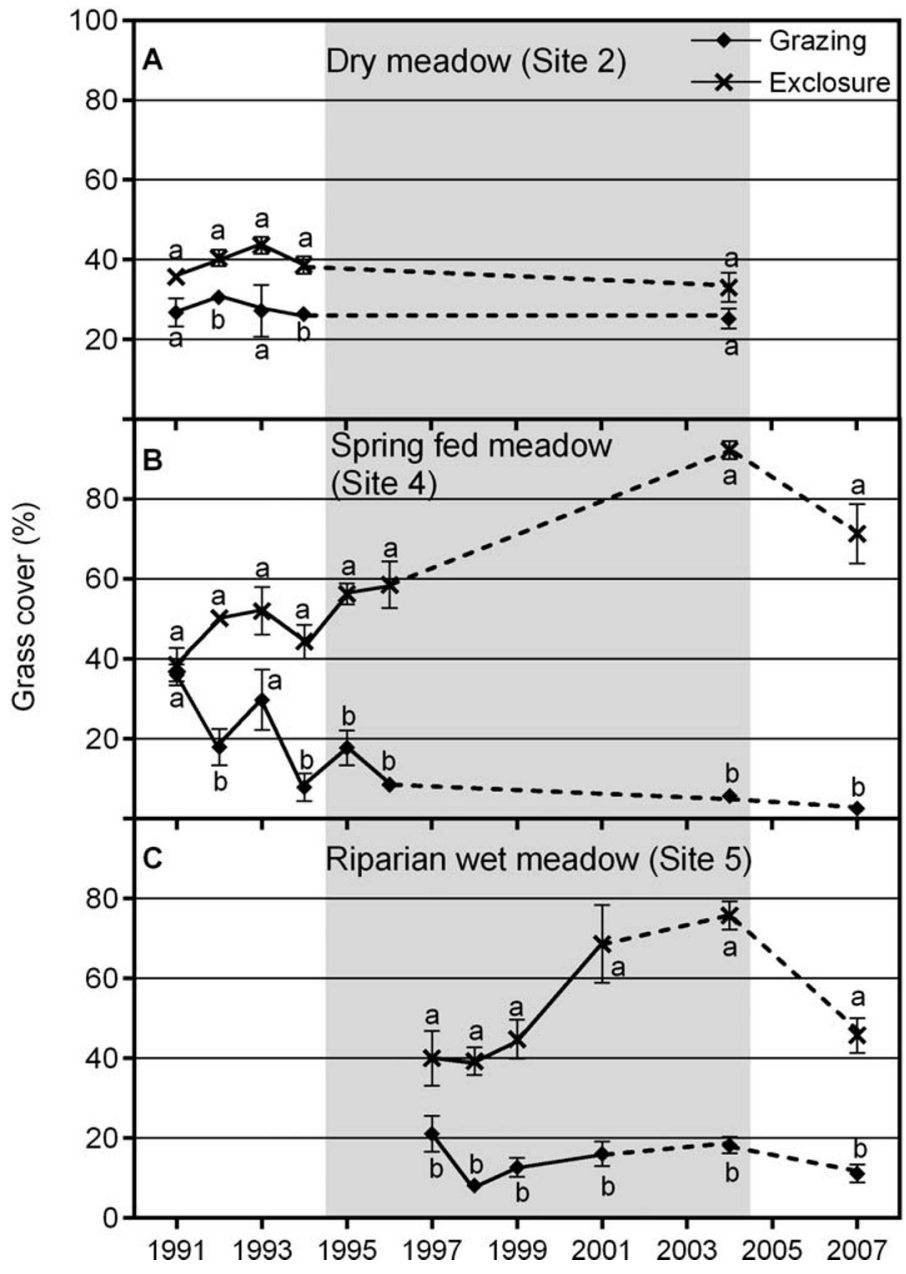

Figure 3. Mean grass cover trajectories ( \pm SE bars) in three Magellanic meadow types. (trajectory sectors longer than $2 \mathrm{yr}$ are shown with dashed lines). The shadowed area indicates the period of drought. Paired yearly means sharing a common letter are not significantly different $(P>0.05)$. A, Dry meadow (Site 2). B, Spring fed meadow (Site 4). C, Riparian wet meadow (Site 5).

more humid sites (E3, E4, E5), but undesirable transitions (cushion shrub encroachment) in the driest meadows (E1, E2).

\section{Life-Form Dynamics}

Grasses. Grass cover dynamics varied according to the grazing condition and the moisture gradient (Fig. 3). In the dry meadow, some significant differences in the exclosure were measured in the initial years before entering the drought cycle, but no differences resulted after $13 \mathrm{yr}$ (Fig. 3A), suggesting little change over time. In the wet meadows, in contrast, grass cover in the exclosures was significantly greater than in the grazing plots after the first year of grazing release and along all the dry cycle (Figs. 3B and 3C). From 2004 to 2007, after the dry period had ended, grass cover decreased in the exclosures of both wet meadows. Two important meadow grasses, $P$. pratensis and Deyeuxia poaeoides (Steud.) Rúgolo, responded favorably to grazing removal but showed different patterns between sites (Fig. 4). After the dry period ended, D. poaeoides increased in the exclosures of both meadows, whereas $P$. 


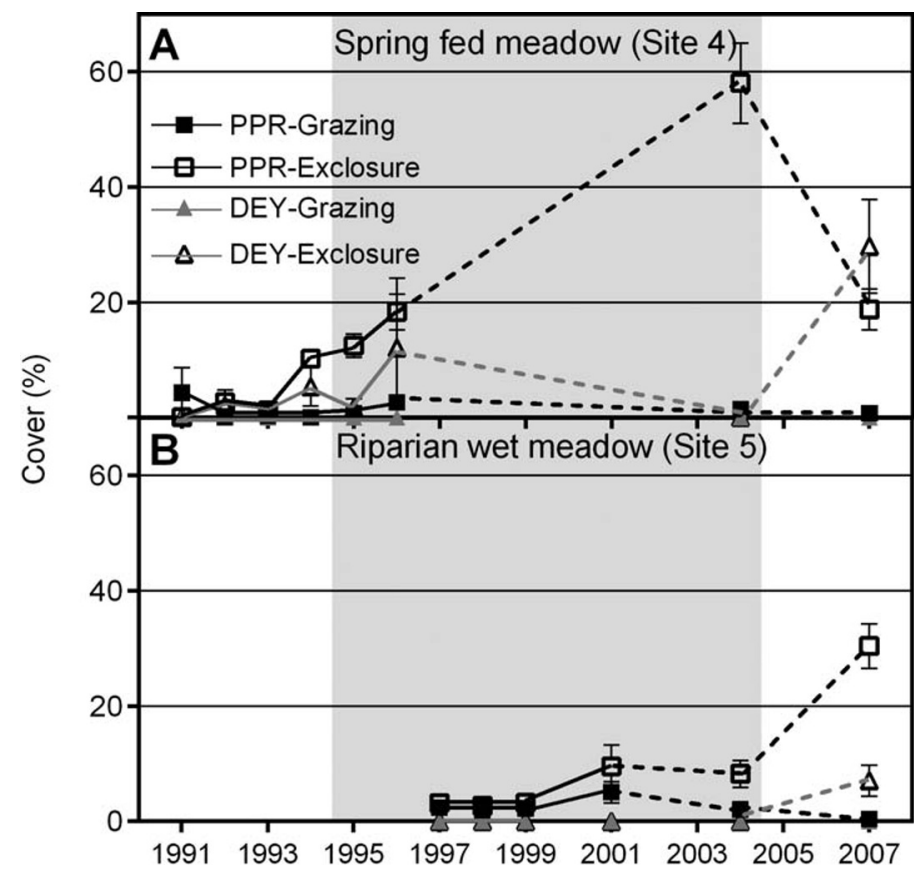

Figure 4. Mean cover trajectories ( \pm SE bars) of Poa pratensis (PPR) and Deyeuxia poaeoides (DEY) in two Magellanic wet meadow types (trajectory sectors longer than $2 \mathrm{yr}$ are shown with dashed lines). The shadowed area indicates the drought period. For the spring-fed meadow, significant differences between treatments occurred in 1994, 1995, and 2004 for PPR, and in 2007 for D. poaeoides (DEY); for the riparian wet meadow, in 2007 PPR and DEY were significantly higher in the exclosure than in the grazed treatment. A, Spring fed meadow (Site 4). B, Riparian wet meadow (Site 5).

pratensis decreased in the exclosure of the spring-fed meadow (site 4) and increased in the riparian wet (site 5).

Caltha. Behavior of this helophyte differed between the mineral soils (sites 2 and 5) and the organic soil (site 4). In the mineral soils (Figs. 5A and 5C), Caltha showed decreased cover during the dry cycle in both treatments, dropping below 20\% in the dry meadow. Conversely, the spring-fed habitat (organic soil) showed an increase in cover of Caltha during the dry cycle in the grazing treatment, but practically disappeared in the exclosure (Fig. 5B). After the end of the dry period, groundwater depth decreased and the cover of Caltha increased notably in the riparian wet meadow (mineral soil), especially in the grazing treatment (Fig. 5C).

Sedges and Rushes. There tended to be more sedges and rushes in the grazed dry meadow than in the exclosure (Fig. $6 \mathrm{~A})$, but this difference was significant in only two cases. Under grazing, sedges and rushes in the spring-fed meadows remained at a high level ( $\sim 50 \%$ cover); after exclosure, cover dropped to about $12 \%$ by 1996 and remained low after that time (Fig. 6B). In the riparian wet meadow, cover of sedges and rushes increased after 2001, with cover under grazing being significantly higher than in exclosures (Fig. 6C).

Cushion Shrubs. This group occurred only in dry meadows. For site 2, there was no difference between grazing treatments, but the cover did increase from 1994 to 2004 during the extended dry period (Fig. 6D).

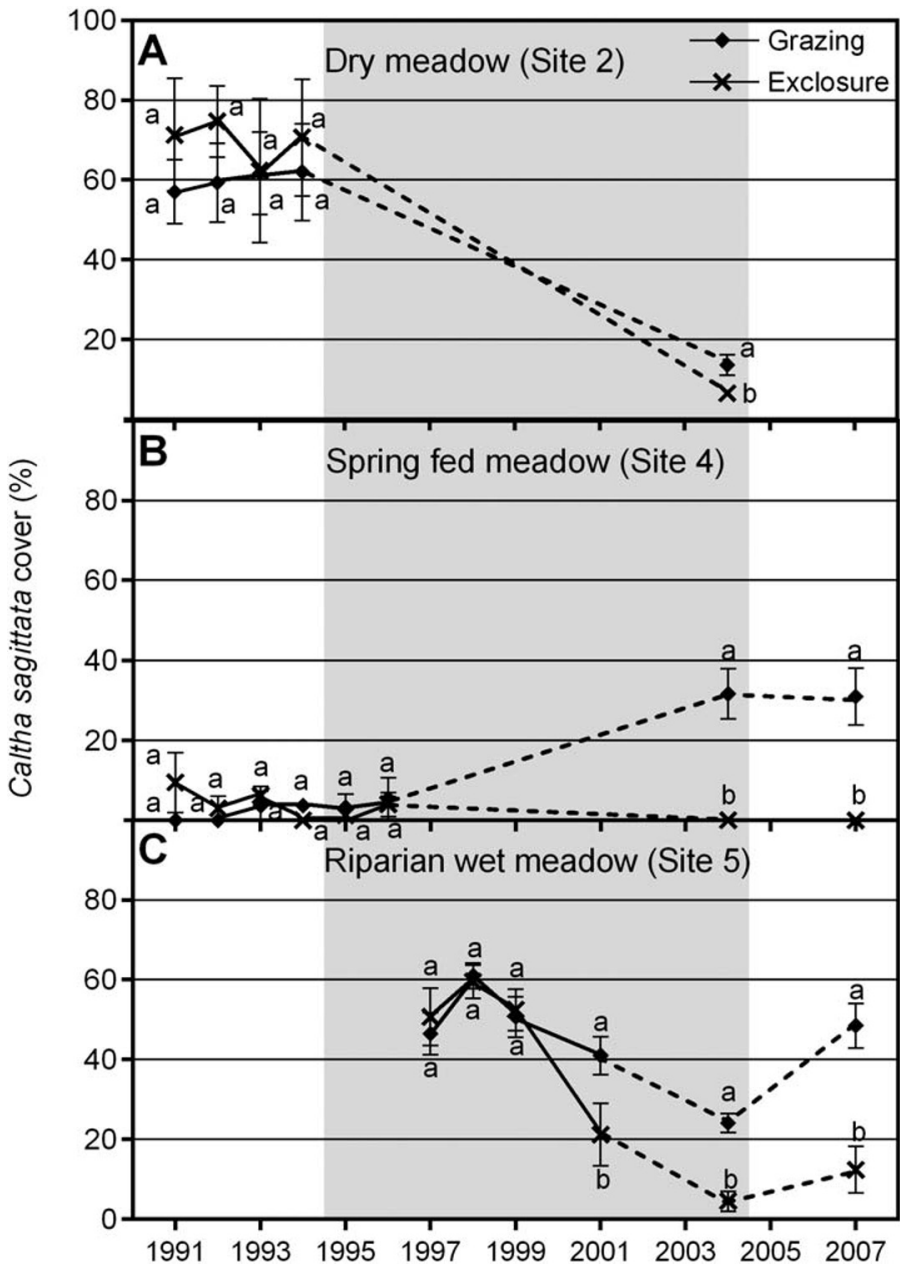

Figure 5. Mean cover trajectories of Caltha sagittata ( \pm SE bars) in three Magellanic meadow types (trajectory sectors longer than 2 yr are shown with dashed lines). The shadowed area indicates the drought period. Paired yearly means sharing a common letter are not significantly different $(P>0.05)$. A, Dry meadow (Site 2). B, Spring fed meadow (Site 4). C, Riparian wet meadow (Site 5).

\section{Long-Term Effect of Exclosure}

We compared grazing vs. exclusion effects on life-forms cover in 2004, after $13 \mathrm{yr}$ (sites 1, 2, and 4) or $7 \mathrm{yr}$ (sites 3 and 5) (Table 4). Grass cover was significantly higher in exclosure treatments, with the exception of the driest sites (1 and 2); however, cover of helophytes and sedges/rushes was higher in the grazing treatments. The cushion shrubs (only present in the dry meadows) showed similar high cover values in both treatments for sites 1 and 2 .

Dry meadows had higher floristic similarities between treatments compared to the wet meadows, and their diversity was not affected by grazing condition (Table 5). In contrast, grazed wet meadows were more diverse than their nongrazed counterparts. No differences in green peak biomass were found between treatments in any site, except that graminoid biomass was higher in the exclosure of the riparian wet meadow (site 5). Attached dead biomass was higher in the exclosures of both wet meadows (Table 5).

Soil compaction was significantly lower in exclosures compared with grazed areas for all sites. The largest differences 


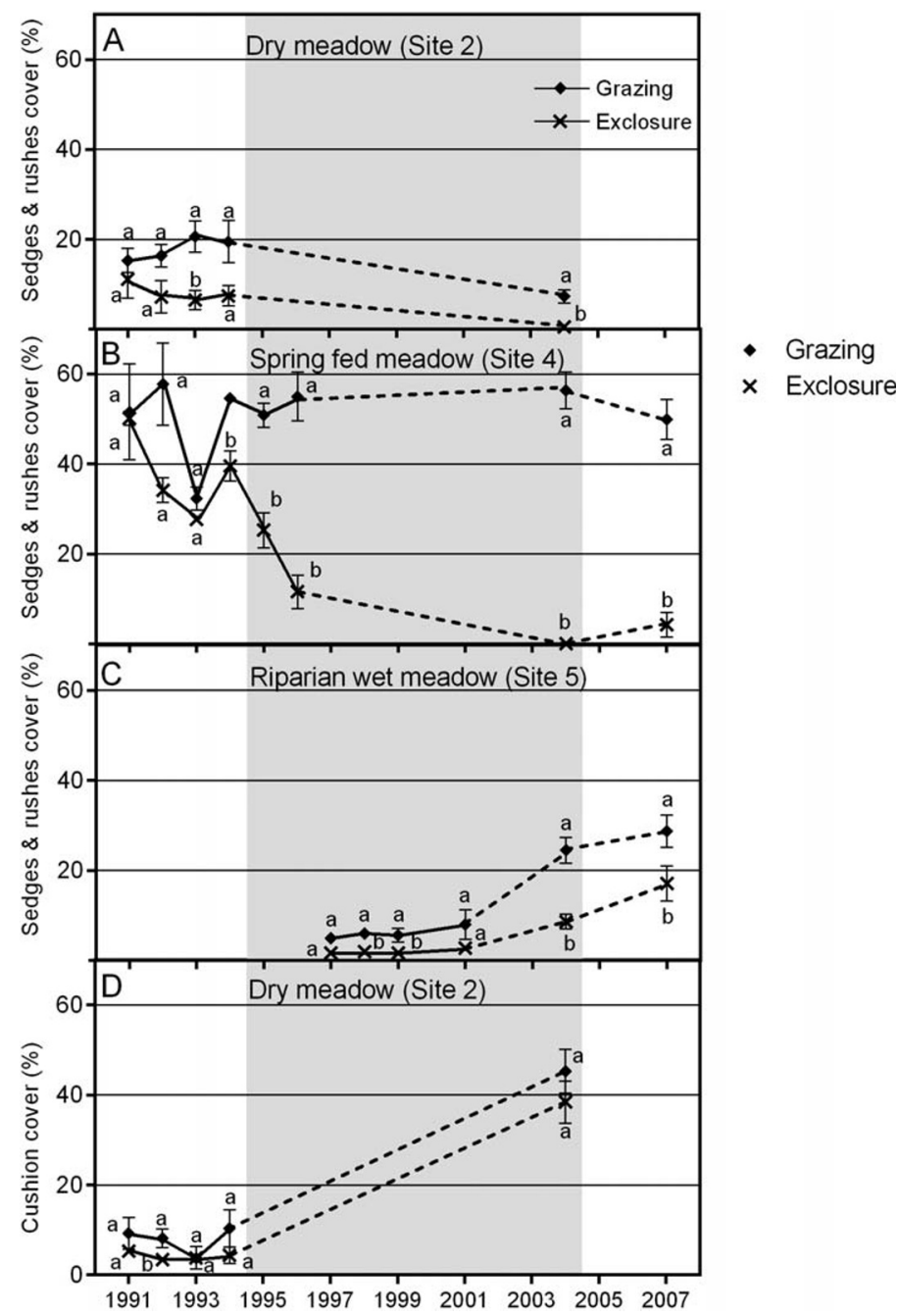

Figure 6. Mean cover trajectories of dwarf sedges and rushes and cushion shrubs ( \pm SE bars) in three Magellanic meadow types (trajectory sectors longer than $2 \mathrm{yr}$ are shown with dashed lines). The shadowed area indicates the drought period. Paired yearly means sharing a common letter are not significantly different $(P>0.05)$. A, Dry meadow (Site 2$)$. B, Spring fed meadow (Site 4). C, Riparian wet meadow (Site 5). D, Dry meadow (Site 2).

occurred in the spring-fed meadow (site 4), with $60 \%$ lower compaction in the exclosure than in the grazed plot (Table 5).

\section{DISCUSSION}

\section{Roles of Climate and Grazing on Vegetation Dynamics}

Vegetation dynamics of Fueguian meadows were affected interactively by hydrological regime and grazing. Most of the study coincided with a long drought (1995-2005), resulting in water tables being at their lowest levels in the summers of 2004 and 2005 (Fig. 1). The drought was made worse by high summer temperatures and high wind velocities during most of that period, increasing potential evapotranspiration by $19 \%$ (Iturraspe and Urciuolo 2002). Meadow vegetation evidenced this xerification process: 8 out of the 12 surveyed plots moved towards the dry extreme of the axis representing the moisture
Table 4. Means (SE) of life-form cover at the final date of the study (2004) for the two grazing treatments of the five meadows having exclosures. Different letters within a site indicate significant differences $(P<0.05)$ using the Mann-Whitney test.

\begin{tabular}{cccccc}
\hline Site & Treatment & $\begin{array}{c}\text { Rhizomatous } \\
\text { helophytes }\end{array}$ & Grasses & $\begin{array}{c}\text { Sedges } \\
\text { \& rushes }\end{array}$ & $\begin{array}{c}\text { Cushion } \\
\text { shrubs }\end{array}$ \\
\hline Dry meadows & & & & \\
$1 \quad$ Grazing & $0.0(0.0)$ & $10.2(1.6)$ & $0.28(0.09) \mathrm{a}$ & $39.0(7.3)$ \\
& Exclosure & $0.0(0.0)$ & $13.1(1.7)$ & $0.05(0.05) \mathrm{b}$ & $54.6(4.3)$ \\
2 & Grazing & $13.6(2.6) \mathrm{a}$ & $25.2(2.5)$ & $7.3(1.4) \mathrm{a}$ & $45.3(4.9)$ \\
& Exclosure & $6.5(1.6) \mathrm{b}$ & $33.1(3.7)$ & $0.47(0.26) \mathrm{b}$ & $38.4(4.7)$ \\
3 & Grazing & $18.5(3.8)$ & $10.8(1.7) \mathrm{a}$ & $23.3(2.8) \mathrm{a}$ & $1.1(0.6) \mathrm{a}$ \\
& Exclosure & $14.0(4.5)$ & $35.2(0.9) \mathrm{b}$ & $1.2(0.44) \mathrm{b}$ & $0.0(0.0) \mathrm{b}$ \\
Wet meadows & & & & \\
4 & Grazing & $31.7(6.3) \mathrm{a}$ & $5.7(1.2) \mathrm{a}$ & $56.4(4.1) \mathrm{a}$ & $0.0(0.0)$ \\
& Exclosure & $0.0(0.0) \mathrm{b}$ & $92.2(2.3) \mathrm{b}$ & $0.02(0.02) \mathrm{b}$ & $0.0(0.0)$ \\
5 & Grazing & $24.1(2.3) \mathrm{a}$ & $18.2(2.0) \mathrm{a}$ & $24.5(8.9) \mathrm{a}$ & $0.0(0.0)$ \\
& Exclosure & $4.6(2.5) \mathrm{b}$ & $75.8(3.5) \mathrm{b}$ & $8.6(1.7) \mathrm{b}$ & $0.0(0.0)$ \\
\hline
\end{tabular}

gradient (axis 1) in the multivariate analysis (Fig. 2). This result agrees with studies reporting a high sensitivity of wetland vegetation to water table fluctuations (Martin and Chambers 2001; Stringham et al. 2001), but contradicts others supporting the view that unlimited water supply in wetlands makes vegetation composition resistant to grazing and weather conditions (Allen-Diaz and Jackson 2000). The large increase in grass cover in exclosures on wet meadows (Figs. 3B and 3C) occurred during the extended dry period. A similar increase in grasses with a large reduction in soil moisture was reported for wet wetlands subjected to artificial drainage (Grotjans et al. 1996).

The main increaser is the exotic P. pratensis (Figs. 4A and $4 \mathrm{~B}$ ), which resists grazing with its aggressive rhizomes and is also a known drought-thriving species in wet meadows of North America (Martin and Chambers 2001). The presence of P. pratensis in the Fuegian steppe was reported in 1895 (Dusén $1905)$, so it probably arrived with the early European voyagers. As the TWINSPAN cluster analysis shows, $P$. pratensis is also an important grass of the driest floristic group, which is characterized here as the Azorella domain (Table 3). With Poa being an increaser in overgrazed sites of the upland steppe (Collantes et al. 1999), and considering the role of invasive species in the response of a system to disturbance (Hobbs and Huenneke 1992), the cover expansion of Poa would suggest that it is driving the system after the severe drought. The encroachment of the most important increaser of Magellanic wetlands, Caltha sagittata, is driven by grazing (Table 4), but also depends on weather conditions (Fig. 5). Collantes et al. (2009) have shown that Caltha avoids permanently flooded soils, which would have caused its contrasting behavior in riparian (Figs. 5A and 5C) vs. spring-fed (Fig. 5B) habitats during the dry cycle. Caltha cover in the riparian wet meadow increased in the two years of above-average rainfall after the end of the dry cycle (Fig. 5C). During the drought, Azorella increased and sedges and rushes decreased in some sites (Fig. $6 \mathrm{~A}$ and $6 \mathrm{~B})$. 
Table 5. Floristic similarity (IS: Sørensen Index) and comparison of means (SE) of diversity (D: Simpson Index), biomass classes and soil compaction between treatments (E: exclosure, G: grazing) of the five meadows having exclosures. Different letters indicate significant differences $(P<0.05)$ using the Mann-Whitney test.

\begin{tabular}{|c|c|c|c|c|c|c|}
\hline Site & IS & $\mathrm{D}$ & Graminoid green biomass $\left(\mathrm{g} \cdot \mathrm{m}^{-2}\right)$ & Total green biomass $\left(\mathrm{g} \cdot \mathrm{m}^{-2}\right)$ & Standing dead biomass $\left(\mathrm{g} \cdot \mathrm{m}^{-2}\right)$ & Soil Compaction $(\mathrm{kPa})$ \\
\hline \multicolumn{7}{|c|}{ Dry meadows } \\
\hline E1 & & $0.60(0.03)$ & $31.8(6.2)$ & $67.8(8.9)$ & $146.9(36.7)$ & $1101.4(79.0) \mathrm{b}$ \\
\hline G1 & 54 & $0.61(0.05)$ & $N D^{1}$ & ND & ND & $2475.9(152.6) \mathrm{a}$ \\
\hline E2 & & $0.68(0.03)$ & $48.4(9.5)$ & $88.4(15.3)$ & $174.0(32.1)$ & $942.9(57.1) \mathrm{b}$ \\
\hline G2 & 67.8 & $0.67(0.03)$ & $81.0(17.4)$ & $146.0(25.2)$ & $114.4(17.5)$ & $1763.7(114.8) \mathrm{a}$ \\
\hline E3 & & $0.74(0.02)$ & $53.7(10.9)$ & $114.0(16.5)$ & $169.9(23.7)$ & $1350.3(55.7) \mathrm{b}$ \\
\hline G3 & 56 & $0.74(0.02)$ & $69.4(12.0)$ & $157.3(18.5)$ & $115.0(19.4)$ & $2364.2(105.2) \mathrm{a}$ \\
\hline \multicolumn{7}{|c|}{ Wet meadows } \\
\hline E4 & & $0.36(0.03) \mathrm{a}$ & $132.0(33.0)$ & $174.2(37.0)$ & $507.2(134.3) \mathrm{b}$ & $789.8(51.7) b$ \\
\hline G4 & 4.3 & $0.53(0.02) b$ & $147.2(11.6)$ & $184.6(13.9)$ & $140.3(11.9) \mathrm{a}$ & $2029.6(119.2) \mathrm{a}$ \\
\hline E5 & & $0.65(0.03) \mathrm{a}$ & $221.8(16.5) b$ & $260.8(21.2)$ & $363.5(54.3) b$ & 1935.8 (91.4) b \\
\hline G5 & 27.8 & $0.80(0.01) b$ & $162.8(13.07) \mathrm{a}$ & $216.9(20.8)$ & $100.1(11.9) \mathrm{a}$ & $2910.4(112.1) \mathrm{a}$ \\
\hline
\end{tabular}

${ }^{1} \mathrm{ND}$, data not collected.

Despite this clear response to precipitation, dynamics of these meadows is driven mainly by grazing, especially in the wet meadows (Figs. 3-6 and Table 4). The response of wet meadows to grazing release is much stronger than that of dry meadows (either for species composition [Fig. 2] or cover [Figs. 3, 5, and 6]). Nevertheless, the dry meadow not encroached by shrubs (site 3) showed an increase in grass cover when exclosed (Table 4). We conclude that grazing drives changes in vegetation composition, as expected for equilibrium systems, confirming results from other riparian habitats (Buttolph and Coppock 2004; Jackson and Allen-Diaz 2006).

\section{Thresholds and Stable States}

The encroachment of Caltha under grazing in some wetlands (G4, G5, G6, G7) and also in the dry meadow under higher rainfall (G3) (Fig. 2), exemplifies a reversible negative transition (i.e., a "phase change" [Stringham et al. 2003; Briske et al. 2005]). This is suggested by the reversion of these sites to grass communities when grazing was excluded (E3, E4, E5). In the two wet grasslands where we followed life-form trajectories (sites 4 and 5), these grassland communities were well established at 4-5 yr after exclosures were installed. Cover of grasses increased and cover of Caltha and sedges and rushes decreased in the exclosures (Figs. 3, 5, and 6). This supports our hypothesis that disturbed states are maintained by grazing. On the other hand, the driest meadows (sites 1 and 2) had the same dominant cushion shrubs as grazing plots at the end of the study (Fig. 2, Table 4), indicating the crossing of a critical structural and functional threshold (i.e., a change of state) (Lopez et al. 2011). Site 2, a more mesic site than site 1, was at first dominated by Caltha, a moisture-loving, wetland-exclusive species that was replaced by Azorella, a woody, mesic species, and so entered the domain of attraction of drier meadows. The lack of change in grass cover in two of the three dry sites (Table 4) indicate that dry meadows do not recover with grazing release, at least under drought conditions.

Based on these results, we modeled alternative states and transitions for wet and dry meadows under the two dominant stressors of the Magellanic region: sheep grazing and drought (Figs. 7 and 8).

The model for wet meadows discriminates between organic and mineral soils. On organic soils (Fig. 7A), overgrazing induced a dwarf graminoid lawn dominated by J. scheuchzerioides (transition 1, may be reversible with grazing control). Drought and increasing grazing are the drivers conducive to Caltha dominance (transitions 2 and 3a), a state that includes a grass phase dominated by $P$. pratensis if grazing is interrupted. Many years of exclosure and above-average rainfall might eventually cause a return to the original state (3b). On mineral soils (Fig. 7B), overgrazing probably causes the shift to the Caltha wet domain directly from the original state (transition 1). A transition to the Caltha dry domain, with increasing soil compaction and xerification (transition 2a), will occur with many years of heavy grazing. In this case, to return to the original state (transition 3), or to the Poa phase (transition $2 \mathrm{~b}$ ) would require external inputs of energy.

For dry meadows, the model proposes different pathways according to soil type. When the water table is $>100 \mathrm{~cm}$ (Fluvisols, Fig. 8A), heavily-grazed dry meadows follow the transition from a hypothetical original state of grasses, forbs, and sedges toward an Azorella-dominated community ("cushion shrub" state II). Although grazing exclusion induces a slight increase in grasses, this transition is probably very difficult to reverse (see Fig. 2, site 1) without external inputs of energy. With a water table $<100 \mathrm{~cm}$ (Mollic Gleysols, Fig. 8B), the original state is converted to a Caltha-dominated community (state II) as a result of overgrazing and probably drought (transition 1a). Within the Caltha state, there is a successional pathway to a grass phase if grazing is suppressed. The persistence of drought drives transition 2 to the Azorella domain (state III), even without overgrazing. Removing shrubs and reseeding grasses is probably the only way for this state to revert to the original state (transition 3).

\section{Functional Consequences of Disturbance}

The most degraded state of these meadows is a dwarf community. If function is viewed as the extent to which water 


\section{WET MEADOWS}

\section{A) Organic soils (Histosols)}

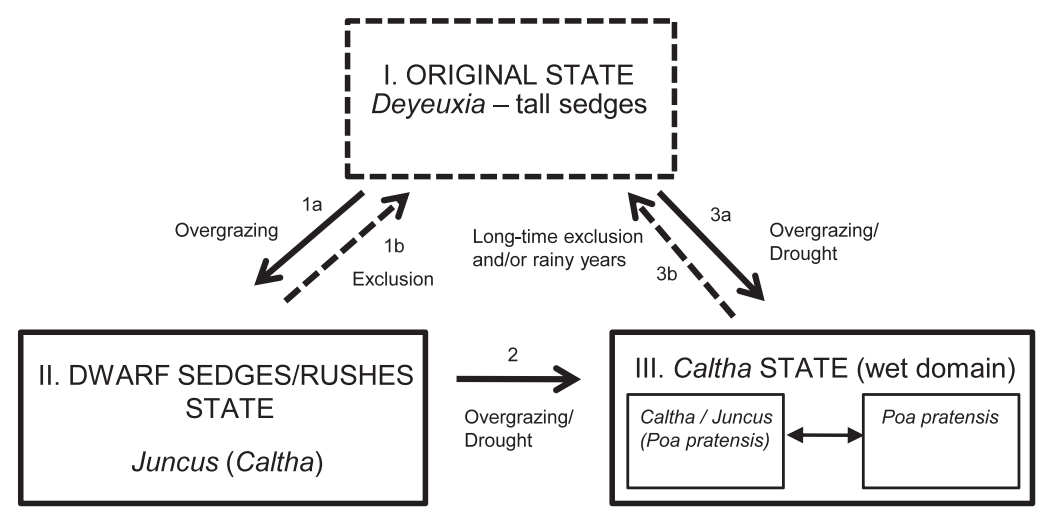

\section{B) Mineral soils (Histic Gleysols)}

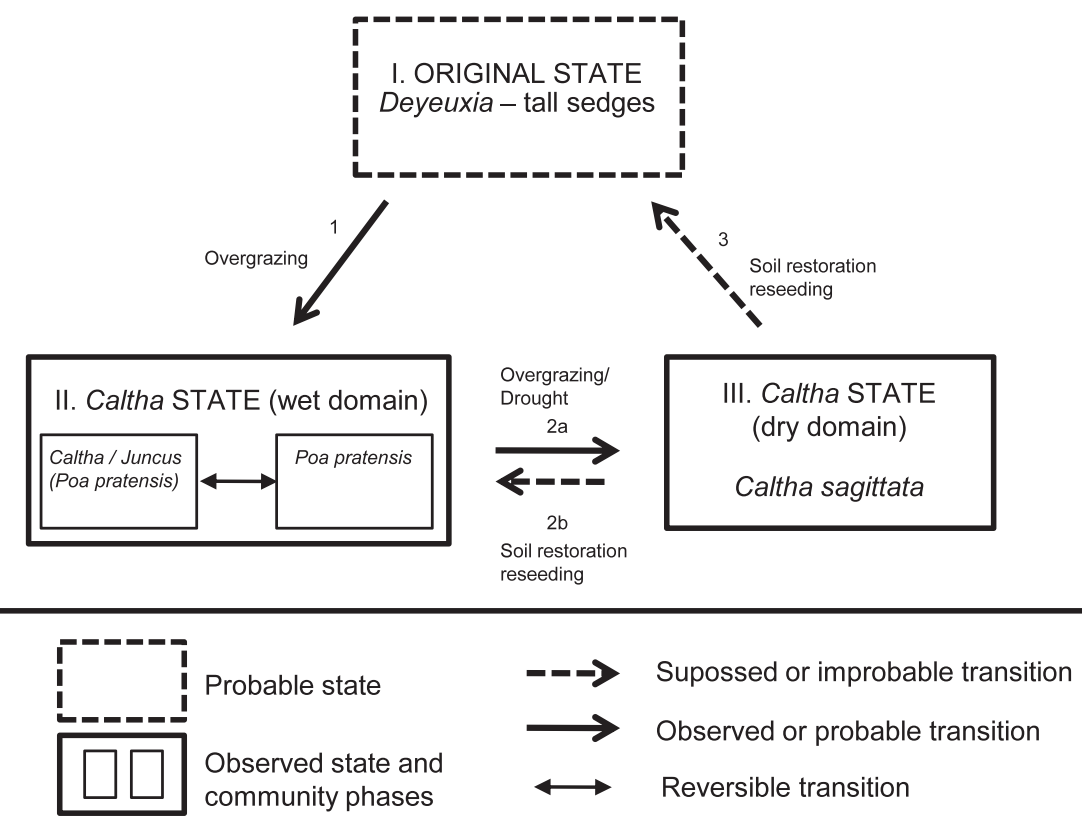

Figure 7. State-and-transition model for wet meadows of the Magellanic steppe, Tierra del Fuego. Deyeuxia is a perennial grass; Juncus ( $J$. scheuchzerioides) is a palatable rush. A, On organic soils, heavy grazing causes transition 1a from grasses and tall sedges to a dwarf graminoid lawn dominated by Juncus (state II). Overgrazing and drought cause transitions 2 or 3 a to the Caltha state III. Within state III, a reversible transition to a Poa pratensis grass phase occurs when grazing is excluded or strongly reduced. Transitions $1 \mathrm{~b}$ and $3 \mathrm{~b}$ would occur, probably, with many years of grazing release. B, On mineral soils, overgrazing causes loss of grasses and Caltha invasion (transition 1) and drives the system to the Caltha wet domain (state II), also having a grass phase dominated by Poa pratensis in abandoned meadows. Persistent grazing, with soil compaction (transition $2 \mathrm{a}$ ), drives the system to the Caltha dry domain (state III). Transitions 2b (to the Poa phase of state II) or 3 would require external inputs of energy.

and nutrients are retained within ecosystems (Briske et al. 2006), the loss of vegetation structure and soil integrity would generate a positive feedback, impairing both the filtration capacity of the vegetation and the infiltration capacity of the soil. This would result in loss of resources by increased evaporation and runoff, with sedimentation of water courses (Wheeler et al. 2002). For dry meadows in the Azorella state, soil compaction is diminished when grazing is prevented (Table 5 ), but this is insufficient for a return to a productive state without the use of intensive management inputs. Probably the long roots of Azorella increased water uptake, lowering the water table and making it less available for grasses and other herbaceous vegetation. In contrast, on wet meadows, removal of grazing for many years favored grasses, as reported in many 


\section{DRY MEADOWS}

\section{A) FLUVISOLS - water table $>100 \mathrm{~cm}$}

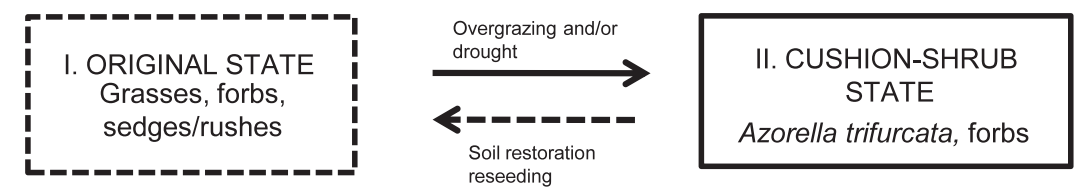

B) MOLLIC GLEYSOLS - water table $<100 \mathrm{~cm}$
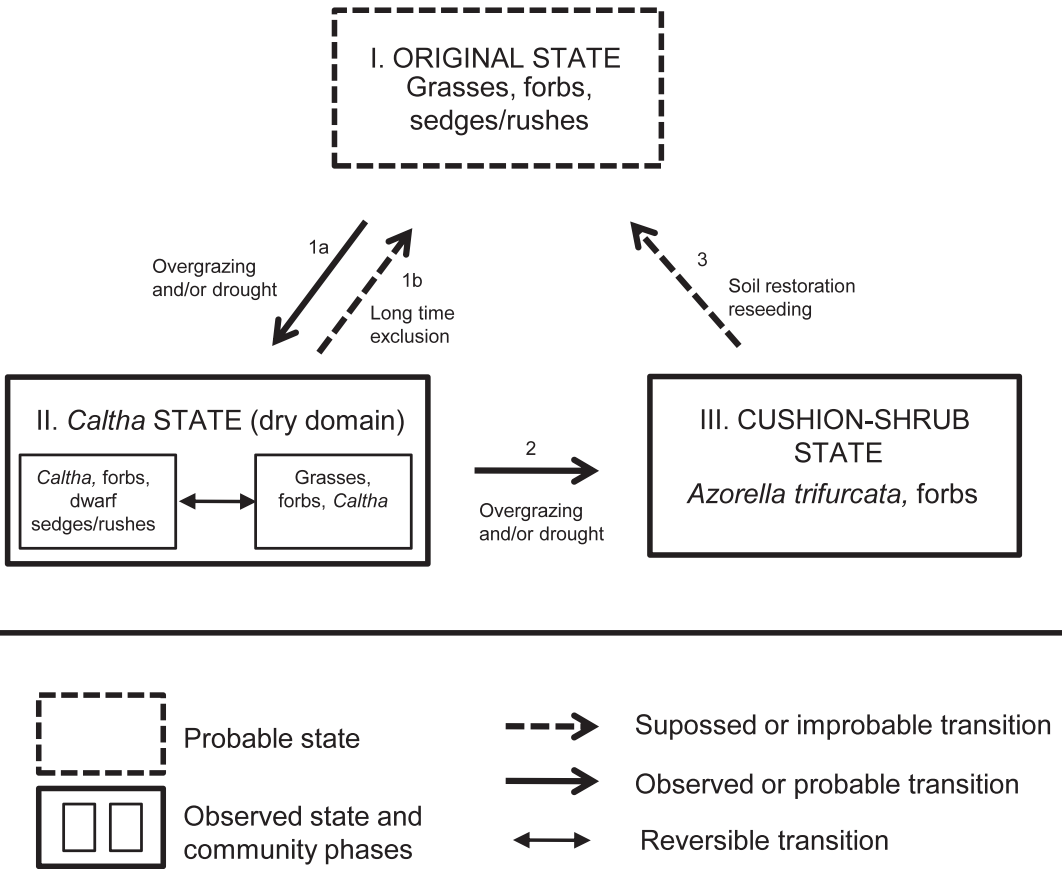

Figure 8. State-and-transition model for dry meadows of the Magellanic steppe in Tierra del Fuego. A, On Fluvisols, overgrazing or drought cause Azorella invasion, a transition to the "cushion shrub" state II. B, On Mollic Gleysols, transition 1a (Caltha invasion) is driven by overgrazing, leading to the "Caltha" state II (dry domain). Within state II, reversible transitions to community phases with a relative cover of grasses occur when grazing is suppressed. Persistent grazing and trampling cause soil compaction and xerification, with transition 2 to the "cushion shrub" state III. Transitions $1 \mathrm{~b}$ and 3 probably require that Caltha or Azorella plants be removed and soil conditions restored.

wetland studies (Smith and Rushton 1994; Clary 1995; Humphrey and Patterson 2000; Buttolph and Coppock 2004). The potential resilience of the wet meadows may be due to the functional redundancy (Naeem 1998) of their grass cover, with many species (up to ten) variously affected by grazing and drought, as shown, for example, by the contrasting behavior of $P$. pratensis and D. poaeoides (Fig. 4A).

\section{Significance of Grazing History}

In systems of high productivity and a long history of grazing, the dissimilarity between grazing plots and exclosures is expected to be higher than in systems of low productivity, because of the persistence of species pools that allow a continuous reversal in composition (Milchunas et al. 1988; Cingolani et al. 2005). This seems to be occurring in the wet meadows surveyed here, according to the large dissimilarity between grazing plots and exclosures (Table 5, IS). The increase in diversity associated with grazing in wet meadows (Table 5, D) is also indicative of systems of high productivity and a long history of grazing, that would follow the intermediate disturbance hypothesis (Cingolani et al. 2005). The decrease in diversity when grazing is interrupted in very wet wetlands may be caused by the high dead biomass accumulated (Table 5, Standing dead biomass), as has been argued by Humphrey and Patterson (2000). This high accumulation of senescent biomass over 13 yr might also prevent any increase in standing crop in the exclosed spring-fed meadow (Table 5, E4), despite its high increase in grass cover (Table 4), because litter accumulation may decrease plant growth (Oesterheld and McNaughton 1991). With 7 yr of litter accumulation, the increase in grass 
cover in the exclosure of the riparian wet meadow (E5) was due to its graminoid biomass (Table 5), mainly composed of grasses, as shown in Table 4.

Dry meadows did not show the expected resilience for a system exposed to a long history of grazing. Although their slower reversal of composition in exclosures can be ascribed to slower demographic processes because of a lower level of resources (Cingolani et al. 2005), we speculate that they have suffered irreversible changes in vegetation and/or soil structure. Dry meadows were probably much more heavily used than wet meadows, considering that degree of use in wetlands is negatively related to surface soil moisture (Bakker and Grootjans 1991; Clary and Booth 1993). Since colonial times, grazing intensities by domestic sheep were probably beyond the historical range experienced by the system. This may have resulted in soil degradation and shrub expansion, causing the slow response of these drier habitats to cessation of grazing (Tables 4 and 5).

\section{MANAGEMENT IMPLICATIONS}

In dry meadows and xerified wet meadows on mineral soils, grazing exclusion alone is not enough to lead to recovery of vegetation to its original state. Achieving recovery might require active management intervention. The Caltha-Poa state in wet meadows probably represents the present state of many of these wet meadows. They should respond to rotational or seasonal grazing and show a succession from the Caltha phase to the Poa phase. Although dry and wet meadows showed a different response to excluding grazing, it is difficult to assign a specific management to each of the meadows, since they generally occur together in the landscape. The best practice would be, when possible, to separate wetlands from upland habitats and to use them in summer or summer-autumn. The study showed the relatively rapid recovery of grasses in the wet meadows, when grazing is prevented, and this is a clear signal that practices such as rotational or seasonal grazing could be effective. This should produce healthy summer pastures, which are badly needed in this high-latitude region.

We have adjusted the state-and-transition model of Collantes et al. (2005), considering several ecological sites having different soils, and including alternative transitions driven by grazing and/or drought (Figs. 7 and 8). These results will contribute to decisions on the application of management or restoration measures in Magellanic meadows, according to the type of habitat and disturbance condition. However, more research is needed to relate stocking rates and weather conditions to ecological thresholds for these wetland types.

\section{ACKNOWLEDGMENTS}

We wish to thank the owners and managers of the estancias of northern Tierra del Fuego for their hospitality and supply of information. We also thank José Bonilla for fieldwork assistance and Enrique Livraghi for logistic and technical advice. Critical comments by Marcelo Aizen and José Anchorena helped to improve the manuscript. We also want to thank the two anonymous reviewers, whose comments and suggestions greatly improved the manuscript.

\section{LITERATURE CITED}

Allen, D. R., ANd C. B. Marlow. 1994. Shoot population dynamics of beaked sedge following cattle grazing. Journal of Range Management 47:64-69.

Allen-Diaz, B., And R. D. Jackson. 2000. Grazing effects on spring ecosystem vegetation of California's hardwood rangelands. Journal of Range Management 53:215-220.

Anchorena, J., A. M. Cingolani, E. Livraghi, M. B. Collantes, and S. Stoffella. 2001. Manejo del pastoreo de ovejas en Tierra del Fuego. Buenos Aires, Argentina: Edipubli Press. $47 \mathrm{p}$.

Armour, C., D. Duff, And W. Elmore. 1994. The effects of livestock grazing on western riparian and stream ecosystems. Fisheries 19:9-12.

BAKKeR, J. P., AND A. P. GrootJans. 1991. Potential for vegetation regeneration in the middle course of the Drentsche A brook valley (The Netherlands). Verhandlungen Gesellschaft für Ökologie 20:249-263.

Bakker, J. P., H. OlfF, J. H. Willens, and M. Zobel. 1996. Why do we need permanent plots in the study of long-term vegetation dynamics? Journal of Vegetation Science 7:147-156.

BeCK, J. L., AND J. M. PeEK. 2004. Herbage productivity and ungulate use of northeastern Nevada mountain meadows. Journal of Range Management 57:376-383.

BeLSKY, A. J. 1987. The effects of grazing: confounding of ecosystem, community and organism scales. American Naturalist 129:777-783.

Belsky, A. J., A. Matzke, and S. Uselman. 1999. Survey of livestock influences on stream and riparian ecosystems in the western United States. Journal of Soil and Water Conservation 54:419-431.

Bork, E. W., and A. M. BuRkinshaw. 2009. Cool-season floodplain meadow responses to shrub encroachment in Alberta. Rangeland Ecology \& Management 62:44-52.

Bradford, J. M. 1986. Penetrability. In: A. Klute [ed.]. Methods of Soil Analysis. Part 1. Physical and Mineralogical Methods. Madison, Wisconsin USA: American Society of Agronomy, Inc. and Soil Society of America, Inc. p 463-478.

Briske, D. D., S. D. Fuhlendorf, and F. E. Smeins. 2005. State-and-transition models, thresholds, and rangelands health: a synthesis of ecological concepts and perspectives. Rangeland Ecology \& Management 58:1-10.

Briske, D. D., S. D. Funlendorf, and F. E. Smeins. 2006. A unified framework for assessment and application of ecological thresholds. Journal of Range Management 59:225-236.

Bryant, H. T., L. E. Blaser, and J. R. Peterson. 1972. Effects of trampling by cattle on bluegrass yield and soil compaction of a Meadowville loam. Agronomy Journal 64:331-334.

ButTolph, L. P., AND D. L. Coppock. 2004. Influence of deferred grazing on vegetation dynamics and livestock productivity in an Andean pastoral system. Journal of Applied Ecology 41:664-674.

Chambers, J. C., AND A. R. LinNerooth. 2001. Restoring riparian meadows currently dominated by Artemisia using alternative state concepts - the establishment component. Applied Vegetation Science 4:157-166.

CIngoLANI, A. M., I. NoY-MeIR, AND S. Diaz. 2005. Grazing effects on rangeland diversity: a synthesis of contemporary models. Ecological Applications 15:757-773.

CLaRY, W. P. 1995. Vegetation and soil responses to grazing simulation on riparian meadows. Journal of Range Management 48:18-25.

Clary, W. P., and G. D. Booth. 1993. Early season utilization of mountain meadow riparian pastures. Journal of Range Management 46:493-497.

Collantes, M. B., J. Anchorena, and A. M. Cingolani. 1999. The steppes of Tierra del Fuego: floristic and growth form patterns controlled by soil fertility and moisture. Plant Ecology 140:61-75.

Collantes, M. B., K. Braun, C. Escartín, A. M. Cingolani, and J. Anchorena. 2005. Patrones de cambio de la vegetación de la estepa fueguina en relación al pastoreo. In: M. Oesterheld, M. Aguiar, C. Ghersa, and J. Paruelo [EDS.]. La heterogeneidad de la vegetación de los agroecosistemas. Buenos Aires, Argentina: Facultad de Agronomía Press. p. 235-251.

Collantes, M. B., J. Anchorena, S. Stoffella, C. Escartín, and R. Rauber. 2009. Wetlands of the Magellanic Steppe (Tierra del Fuego, Argentina). Folia Geobotanica 44:227-245.

Dusén, P. 1905. Die Pflanzenvereine der Magellansländer nebst einem Beitrage zur Ökologie der Magellanischen Vegetation. Svenska Expeditionen. Magellansländerna 3(10):351-521. 
FriedEL, M. H. 1991. Range condition assessment and the concept of thresholds: a viewpoint. Journal of Range Management 44:422-426.

Green, D. M., AND J. B. KaufFMan. 1995. Succession and livestock grazing in a northeastern Oregon riparian ecosystem. Journal of Range Management 48:307313.

Grootjans, A. P., L. F. M. Fresco, C. C. de Leeuw, and P. C. Schipper. 1996. Degeneration of species-rich Calthion palustris hay meadows; some considerations on the community concept. Journal of Vegetation Science 7:185-194.

HobBS, R.S., AND L. F. Huenneke. 1992. Disturbance, diversity and invasion: implications for conservation. Conservation Biology 6:324-337.

Humphrey, J. W., and G. S. Patterson. 2000. Effects of late summer cattle grazing on the diversity of riparian pasture vegetation in an upland conifer forest. Journal of Applied Ecology 37:986-996.

InfoStat. 2008. InfoStat Versión 2008. Editorial Brujas, Argentina: Grupo InfoStat, FCA, Universidad Nacional de Córdoba.

IturRaspe, R. J., and A. B. Urciuolo. 2002. Ciclos deficitarios en el régimen de sistemas lagunares de la estepa fueguina. In: Comité Permanente de los Congresos Nacionales del Agua [ED]. XIX Congreso Nacional del Agua; Agosto 2002; Villa Carlos Paz, Argentina. p. 99-104.

JaCKSON, R. D., AND B. Allen-Diaz. 2006. Spring-fed wetland and riparian plant communities respond differently to altered grazing intensity. Journal of Applied Ecology 43:485-498.

JenSEn, K., AND J. Schrautzer. 1999. Consequences of abandonment for a regional fen flora and mechanisms of successional change. Applied Vegetation Science 2:79-88.

LauenRoth, W. K. 1998. Guanacos, spiny shrubs and the evolutionary history of grazing in the Patagonia steppe. Ecología Austral 8:211-215.

López, D. R., L. Cavallero, M. A. Brizuela, and M. R. Aguiar. 2011. Ecosystemic structural-functional approach of the state and transition model. Applied Vegetation Science 14:6-16.

Lucas, R. W., T. T. Baker, M. K. Wood, C. D. Allison, and D. M. Vanleeuwen. 2004. Riparian vegetation response to different intensities and seasons of grazing. Journal of Range Management 57:466-474.

Martin, D. W., AND J. C. Chambers. 2001. Restoring degraded riparian meadows: biomass and species responses. Journal of Range Management 54:284-291.

Matěsková, I., R. van Diggelen, and K. Prach. 2003. An attempt to restore a central European species-rich mountain grassland through grazing. Applied Vegetation Science 6:161-168.

McCune, B., and J. B. Grace. 2002. Analysis of ecological communities. Gleneden Beach, OR, USA: MjM Software Design. 300 p.
Midoleton, B. 2002. Nonequilibrium dynamics of sedge meadows grazed by cattle in southern Wisconsin. Plant Ecology 161:89-110.

Middleton, B. A., B. Holsten, and R. van Diggelen. 2006. Biodiversity management of fens and fen meadows by grazing, cutting and burning. Applied Vegetation Science 9:307-316.

Milchunas, D. G., O. E. Sala, and W. K. Lauenroth. 1988. A generalized model of the effects of grazing by large herbivores on grassland community structure. American Naturalist 132:87-106.

Mueller-Dombois, D., and H. Ellenberg. 1974. Aims and methods of vegetation ecology. New York, NY, USA: J. Wiley \& Sons Press. 547 p.

NAEEM, S. 1998. Species redundancy and ecosystem reliability. Conservation Biology 12:39-45.

Oesterheld, M., and S. J. McNaughton. 1991. Effect of stress and time of recovery on the amount of compensatory growth after grazing. Oecologia 85:305-313.

RAEDEKE, K. J. 1980. Food habits of the guanaco (Lama guanicoe) of Tierra del Fuego, Chile. Turrialba 30:177-181.

Schulz, T. T., AND W. C. Leininger. 1990. Differences in riparian vegetation structure between grazed areas and exclosures. Journal of Range Management 43:295299.

Smith, R. S., And S. P. Rushton. 1994. The effects of grazing management on the vegetation of mesotrophic (meadow) grassland in Northern England. Journal of Applied Ecology 31:13-24.

Stammel, B., K. Kiehl, and J. Pfadenhauer. 2003. Alternative management on fens: response of vegetation to grazing and mowing. Applied Vegetation Science $6: 245-254$.

Stringham, T. K., W. C. Krueger, and P. L. Shaver. 2003. State and transition modeling: an ecological approach. Journal of Range Management 56:106-113.

Stringham, T. K., W. C. Krueger, and D. R. Thomas. 2001. Application of nonequilibrium ecology to rangeland riparian zones. Journal of Range Management 54:210-217.

Weixelman, D. A., D. C. Zamudio, and R. J. Tausch. 1997. Classifying ecological types and evaluating site degradation. Journal of Range Management 50:315-321.

Wheeler, M. A., M. J. Trlica, G. W. Frasier, and J. D. Reeder. 2002. Seasonal grazing affects soil physical properties of a montane riparian community. Journal of Range Management 55:49-56.

Wright, J. M., AND J. C. Chambers. 2002. Restoring riparian meadows currently dominated by Artemisia using alternative state concepts - above-ground vegetation response. Applied Vegetation Science 5:237-246. 